\title{
A dataset of forest volume deadwood estimates for Europe
}

\author{
Nicola Puletti ${ }^{1}$ (D) $\cdot$ Roberto Canullo $^{2,3} \cdot$ Walter Mattioli $^{1} \cdot$ Radosław Gawryś $^{4} \cdot$ Piermaria Corona $^{1} \cdot$ Janusz Czerepko $^{4}$
}

Received: 29 April 2018 / Accepted: 4 April 2019 / Published online: 27 June 2019

(C) INRA and Springer-Verlag France SAS, part of Springer Nature 2019

\begin{abstract}
- Key message ICP-Forests relies on a representative pan-European network based on a $16 \times 16 \mathrm{~km}$ grid-net covering around 6,000 plots. Dead wood volumes for 3,243 plots, related to 19 European Countries, are presented in this data paper as a result of harmonised sampling procedure, and under compliance with FAIR Data Principles. Dataset access is at https://doi.org/10.5281/zenodo.1467784. Associated metadata are available at https://metadata-afs. nancy.inra.fr/geonetwork/srv/fre/catalog.search\#/metadata/a27d2a8f-1a2d-4a1c-b932-86ec5f4bd8a6.
\end{abstract}

Keywords Deadwood decay classes $\cdot$ Stand management $\cdot$ Stand age $\cdot$ European Forest Types $\cdot$ ICP Forests monitoring programme

\section{Background}

Deadwood covers a fundamental role in forest ecosystems because stocks huge quantities of forest carbon and is a relevant resource for a wide range of organisms (Zell et al. 2009). Therefore, it has been recognised as one of the most important structural and multifunctional components of many forest ecosystems and selected as criterion of the pan-European indicators for sustainable forest management (Lassauce et al. 2011).

Despite its importance, studies, information, and statistics on forest deadwood on very large scales are scarce or missing

Handling Editor: Marianne Peiffer

Contribution of the co-authors Nicola Puletti: analysing data and computations, writing of the manuscript, metadata description, and corresponding author

Roberto Canullo: supervising the project, writing of the manuscript

Walter Mattioli: writing of the manuscript, metadata description

Radosław Gawryś: analysing and compiling data

Piermaria Corona: writing of the manuscript

Janusz Czerepko: writing of the manuscript, analysing data

Nicola Puletti

nicola.puletti@crea.gov.it

1 Consiglio per la ricerca in agricoltura e l'analisi dell'economia agraria (CREA), Research Centre for Forestry and Wood, Viale Santa Margherita, 80, 52100 Arezzo, Italy
(Seibold et al. 2015). Current experiences are based on data collected through National Forest Inventories (NFIs) (Rondeux et al. 2012) or forest inventories at subnational scale (e.g. Corona et al. 2010; Lombardi et al. 2015), but the lack of standardised deadwood-related definitions makes the comparison of estimates from different countries hard (Ståhl et al. 2012).

The ICP Forests programme (http://www.icp-forests.org) is the only existing network that monitors the status of forests under a coordinated pan-European umbrella, using common standards and harmonised methods for data collection. This involved also tree stand and biodiversity issues, including deadwood
2 School of Biosciences and Veterinary Medicine - Plant Diversity and Ecosystems Management unit, University of Camerino, V. Pontoni, 5, 62032 Camerino, Italy

3 Department of Environmental Science, Botany \& Ecology Section, University of Camerino, Via Pontoni, 5, I -, 62032 Camerino, MC, Italy

4 Forest Research Institute (IBL), Sękocin Stary, Braci Leśnej Street No. 3, PL-05090 Raszyn, Poland 
measurements, which represents a unique opportunity to develop comparable deadwood volume estimates at regional level.

The aim of the data paper is to increase the diffusion of a highvalue dataset, providing the added-value results of harmonised sampling procedure and moving, at the same time, towards the compliance with the FAIR principles (Wilkinson et al. 2016).

\section{Methods}

ICP Forests Programme is responsible for level I and more detailed level II monitoring system of forest sites (Haußmann and Fischer 2004; Ferretti and Fischer 2013), which have been in operation since 1986 and 1994, respectively. The largescale level I network is dedicated to investigations on forest condition monitoring and was built as a dense and spatially representative $16 \times 16 \mathrm{~km}$ virtual grid of forest sampling points placed over Europe. Around these points, a system of three circular concentric subplots with areas respectively of 30 $\mathrm{m}^{2}, 400 \mathrm{~m}^{2}$, and $2000 \mathrm{~m}^{2}$ were built, and data on stand structure and biodiversity have been collected, based on common definitions and protocols, as described below, together with the measures and assessments used for further calculations (Bastrup-Birk et al. 2008).

In this study, basic data collected between 2006 and 2008, from 3243 level I-subplot 2 (ICP Forests LI-sub2, the ones within $400 \mathrm{~m}^{2}$ subplots) have been extracted, pre-processed, and merged. The 19 European Countries involved were France, Belgium, Germany, Italy, the UK, Ireland, Denmark, Spain, Sweden, Austria, Finland, Hungary, Poland, Slovak Republic, Lithuania, Czech Republic, Slovenia, Latvia, and Cyprus (Fig. 1; Canullo 2016; Puletti et al. 2017).

\subsection{Definitions of deadwood components, mandatory measures, and measures conditions}

Various deadwood categories have been considered and measured (Table 1): standing and lying dead trees, coarse woody debris, snags, and stumps. Here, following the used definitions are reported (Bastrup-Birk et al. 2008):

- a standing dead tree (SDT) is defined as dead tree not lying on the forest floor, to be measured as DBH and total height;

- conversely, lying dead tree (LDT) defines any dead trees lying on the forest floor. LDT is considered when the rooted part falls within the plot. Mandatory measures are $\mathrm{DBH}$ and total height;

- coarse woody debris (CWD) includes stems, limbs, branches lying on the forest floor, and with a diameter at the thicker end of the debris larger than $10 \mathrm{~cm}$. CWD pieces must be detached from a bole and not selfsupported by a root system. Such CWD are surveyed if more than $50 \%$ of its thicker end lies within the plot. Mandatory measures are total length and diameter at half-length;

- a snag is defined as pieces of standing dead trees (i.e. standing dead wood) without branches, and is measured as total length and diameter at half-length;

- a stump is defined as a short vertical piece, lower than 1.3 $\mathrm{m}$, resulting both from cutting or natural processes. Stumps are measured in height from the ground and diameter of the top section.

\subsection{Deadwood volume calculation}

Starting from the above basic measurements, the wood volume of SDT and LDT was calculated by the following equation:

$V_{\text {tree }}=f \cdot H_{\text {tot }} \cdot \pi / 4 \cdot D B H^{2}$

where $V_{\text {tree }}$ is the volume expressed in $\mathrm{m}^{3}, H_{\text {tot }}$ is the total tree height expressed in $\mathrm{m}, D B H$ is the diameter at breast height expressed in $\mathrm{m}$, and the shape coefficient $f$ was set equal to 0.5 , because a species-specific value is not available for all the considered tree species.

The volume of snags and CWD elements was calculated by the following equation:

$V_{\text {snag } / \text { cwd }}=\pi / 4 \cdot l_{\text {tot }} \cdot d_{\text {half }^{2}}$

where $V_{\text {snag/cwd }}$ is the volume expressed in $\mathrm{m}^{3}, d_{\text {half }}$ is the diameter at half-length expressed in $\mathrm{m}$, and $l$ is the length of the element expressed in $\mathrm{m}$.

The volume of each stump was calculated as follows:

$V_{\text {stump }}=\pi / 4 \cdot h_{\text {cut }} \cdot d_{\text {cut }}$

where $V_{\text {stump }}$ is the volume of the stump expressed in $\mathrm{m}^{3}$, $d_{\text {cut }}$ is the top section diameter of the stump expressed in $\mathrm{m}$, and $h_{\text {cut }}$ is the height of this section from the ground, expressed in $\mathrm{m}$.

\subsection{Decay status}

Decay status (DEC) of each dead element were recorded for all the five components and reported in the original datasets. Decay level classification of each deadwood piece was visually assessed by the system proposed by Hunter (1990). Such classification uses simultaneously both morphological features of deadwood, presence of bark, integrity of wood structure, and wood colour to classify deadwood elements into five decay levels: (1) 
Fig. 1 Spatial distribution of ICP forest LI-sub2 points considered in the dataset (in black). In darkgrey, the 19 Countries containing the selected points (for map details, please see Puletti et al. 2017)

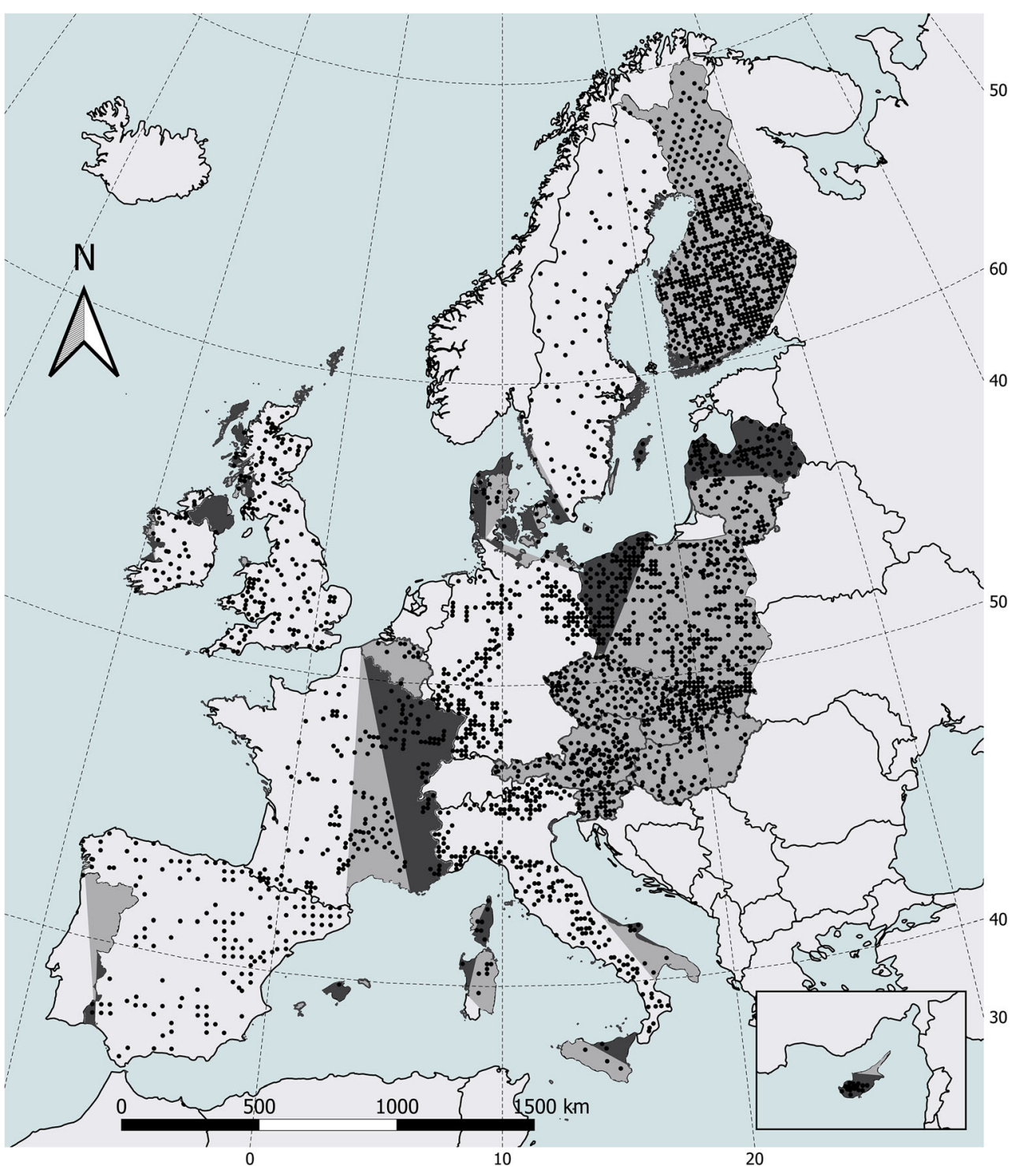

unknown: is not possible to identify a class; $5, N A$ : information is not available/collected.

\subsubsection{Stand age}

The stand age parameter was assigned to each plot adopting nine forest age classes. One class is specific for uneven-aged stands, seven classes for even-aged stands (six classes of width equal to 20 years in the range $0-120$ and one for stands with age higher than 120 years), and the remaining class was adopted for those stands whose age class was not assessed on the field.

\subsubsection{EFTC}

European Forest Types and Categories have been attributed to each plot, following the system adopted by European Environmental Agency (EEA 2006; Barbati et al. 2014). managed: human activities were clear and undeniable; 4 ,

Forest stand management ranges among five possible classes: 1, unmanaged: no evidences of management; 2 , management: evidence of past management (more than 10 years ago); 3 , 
Table 1 Mandatory measures of deadwood elements, in ICP Forests Level I plots, according to deadwood type and description of deadwood type

\begin{tabular}{|c|c|c|}
\hline $\begin{array}{l}\text { Mandatory measures of } \\
\text { deadwood elements }\end{array}$ & Deadwood type & Description of deadwood type \\
\hline \multirow[t]{2}{*}{$\begin{array}{l}\text { DBH: diameter at breast height } \\
H_{\text {tot }} \text { total height }\end{array}$} & $S D T$ : standing dead trees & $\begin{array}{l}\text { A standing dead tree recorded if } \\
\qquad \mathrm{DBH} \geq 10 \mathrm{~cm} \text { and } H_{\mathrm{tot}} \geq 1.3 \mathrm{~m}\end{array}$ \\
\hline & $L D T$ : lying dead trees & $\begin{array}{l}\text { Lying dead trees was recorded if } \\
\mathrm{DBH} \geq 10 \mathrm{~cm}\end{array}$ \\
\hline \multirow[t]{2}{*}{$\begin{array}{l}l_{\text {tot }}: \text { total length } \\
d_{\text {half: diameter at half-length }}\end{array}$} & snag & $\begin{array}{l}\text { Snag recorded if } l_{\text {tot }} \geq 1.3 \mathrm{~m} \text { and } \\
\quad d_{\text {half }} \geq 10 \mathrm{~cm}\end{array}$ \\
\hline & $C W D$ : coarse woody debris & $C W D$ recorded if $d_{\text {half }}>10 \mathrm{~cm}$ \\
\hline $\begin{array}{l}h_{\text {cut }}: \text { height from the ground } \\
d_{\text {cut }}: \text { diameter of the top section }\end{array}$ & stump & $\begin{array}{l}\text { Stump recorded if } h_{\text {cut }}<1.3 \mathrm{~m} \\
\quad \text { and } d_{\text {cut }} \geq 10 \mathrm{~cm}\end{array}$ \\
\hline
\end{tabular}

\section{Access to the data \& metadata description}

The data are freely accessible from Puletti et al. (2018) at https://doi.org/10.5281/zenodo.1467784. Associated metadata is available at https://metadata-afs.nancy.inra.fr/ geonetwork/srv/fre/catalog.search\#/metadata/a27d2a8f-1a2d4a1c-b932-86ec5f4bd8a6.

In Zenodo repository, eight files can be found. The most important is the "Reference dataframe.csv" file containing all the 3243 plots with volume values in columns. Other five files, namely, "Age classes.csv", "Country.csv", "Management.csv", and "EFTC.csv", describe codes contained respectively in the columns age, country, manage, and EFTC and the file "Decay status.csv" contributes to understand tail of code in several columns of the "Reference dataframe.csv". The file "calculation. R" is an R script allowing preliminary calculations, as performed also in this paper.

Lastly, the file "Excerpt from BE Demonstratieproject_biosoil_2008.pdf" fits with Bastrup-Birk et al. (2008).

\section{Results and technical validation}

A total of about 38,000 deadwood elements have been considered in the database here presented, with 1738 SDTs, 338 LDTs, 10,904 CWD, 2606 snags, and 22,414 stumps. Some general results and considerations from these data are following reported.
Table 2 Mean values of deadwood volume $\left(\mathrm{m}^{3} \mathrm{ha}^{-1}\right)$ and their $95 \%$ confidence interval estimates distinguished by Country and deadwood type (see the text for acronyms)

\begin{tabular}{llllllll}
\hline Country & SDT & LDT & Snag & CWD & Stump & Number of plots & Mean volume \\
\hline Austria & $9.1^{ \pm 2.9}$ & 0.0 & 0.0 & $14.6^{ \pm 3.3}$ & 0.0 & 136 & $23.7^{ \pm 4.6}$ \\
Belgium & $4.8^{ \pm 2.4}$ & $6.0^{ \pm 4.8}$ & $1.3^{ \pm 1.3}$ & $3.6^{ \pm 2.3}$ & $1.0^{ \pm 0.2}$ & 10 & $17.5^{ \pm 8.1}$ \\
Cyprus & $0.2^{ \pm 0.2}$ & $1.0^{ \pm 0.6}$ & $24.9^{ \pm 24.9}$ & $0.2^{ \pm 0.2}$ & $0.5^{ \pm 0.3}$ & 19 & $26.9^{ \pm 24.8}$ \\
Czech Rep. & 0.0 & 0.0 & 0.0 & $3.8^{ \pm 0.7}$ & $5.7^{ \pm 0.5}$ & 146 & $9.8^{ \pm 1.0}$ \\
Denmark & $1.4^{ \pm 0.9}$ & 0.0 & 0.0 & $4.8^{ \pm 3.2}$ & 0.0 & 22 & $6.2^{ \pm 3.2}$ \\
Finland & $1.6^{ \pm 0.3}$ & $0.6^{ \pm 0.2}$ & $0.4^{ \pm 0.1}$ & $2.1^{ \pm 0.2}$ & $2.4^{ \pm 0.1}$ & 630 & $7.1^{ \pm 0.5}$ \\
France & $7.9^{ \pm 1.9}$ & 0.0 & $2.0^{ \pm 0.4}$ & $9.7^{ \pm 1.0}$ & $2.2^{ \pm 0.1}$ & 548 & $22.3^{ \pm 2.4}$ \\
Germany & $3.3^{ \pm 0.8}$ & $1.3^{ \pm 0.4}$ & $7.0^{ \pm 2.5}$ & $11.9^{ \pm 1.1}$ & $5.8^{ \pm 0.5}$ & 226 & $29.6^{ \pm 3.0}$ \\
Hungary & $3.6^{ \pm 1.5}$ & $0.1^{ \pm 0.1}$ & $1.1^{ \pm 0.4}$ & $3.9^{ \pm 1.0}$ & $0.7^{ \pm 0.2}$ & 78 & $9.7^{ \pm 1.9}$ \\
Ireland & 0.0 & 0.0 & 0.0 & $1.4^{ \pm 0.4}$ & $4.5^{ \pm 1.1}$ & 35 & $6.1^{ \pm 1.4}$ \\
Italy & $5.8^{ \pm 1.3}$ & $1.3^{ \pm 0.5}$ & $2.7^{ \pm 1.6}$ & $2.7^{ \pm 0.5}$ & $2.0^{ \pm 0.3}$ & 224 & $14.9^{ \pm 2.4}$ \\
Latvia & $7.1^{ \pm 1.3}$ & $3.8^{ \pm 1.6}$ & $3.0^{ \pm 0.8}$ & $10.7^{ \pm 1.6}$ & $1.2^{ \pm 0.2}$ & 95 & $26.4^{ \pm 3.2}$ \\
Lithuania & $5.8^{ \pm 2.0}$ & $5.4^{ \pm 3.2}$ & $1.5^{ \pm 0.4}$ & $3.0^{ \pm 0.7}$ & $2.0^{ \pm 0.3}$ & 62 & $17.7^{ \pm 3.9}$ \\
Poland & $2.4^{ \pm 1.1}$ & $0.1^{ \pm 0.0}$ & $0.8^{ \pm 0.3}$ & $3.9^{ \pm 0.8}$ & $2.6^{ \pm 0.2}$ & 438 & $9.9^{ \pm 1.8}$ \\
Slovak Rep. & $9.7^{ \pm 2.1}$ & 0.0 & 0.0 & $12.1^{ \pm 1.8}$ & $4.8^{ \pm 0.5}$ & 108 & $27.3^{ \pm 3.5}$ \\
Slovenia & $18.3^{ \pm 7.6}$ & $5.0^{ \pm 2.0}$ & $0.9^{ \pm 0.4}$ & $5.2^{ \pm 1.5}$ & $3.2^{ \pm 0.5}$ & 44 & $33.1^{ \pm 7.8}$ \\
Spain & $1.8^{ \pm 0.5}$ & $0.1^{ \pm 0.1}$ & $0.5^{ \pm 0.2}$ & $2.1^{ \pm 0.5}$ & $1.0^{ \pm 0.2}$ & 155 & $5.6^{ \pm 0.9}$ \\
Sweden & $2.4^{ \pm 1.2}$ & $2.3^{ \pm 1.1}$ & $3.2^{ \pm 0.8}$ & $15.3^{ \pm 3.5}$ & $1.1^{ \pm 0.1}$ & 100 & $24.4^{ \pm 5.2}$ \\
United Kingdom & 0.0 & 0.0 & $4.7^{ \pm 2.7}$ & $9.3^{ \pm 1.9}$ & $1.3^{ \pm 0.2}$ & 167 & $15.5^{ \pm 4.2}$ \\
EU19 & $4.1^{ \pm 0.4}$ & $0.7^{ \pm 0.1}$ & $1.8^{ \pm 0.3}$ & $6.4^{ \pm 0.3}$ & $2.5^{ \pm 0.1}$ & 3243 & $15.8^{ \pm 0.7}$ \\
\hline & & & & & & & \\
\hline
\end{tabular}


Fig. 2 Frequency distribution of plots in deadwood volume quantity classes with size of $25 \mathrm{~m}^{3} \mathrm{ha}^{-1}$ each

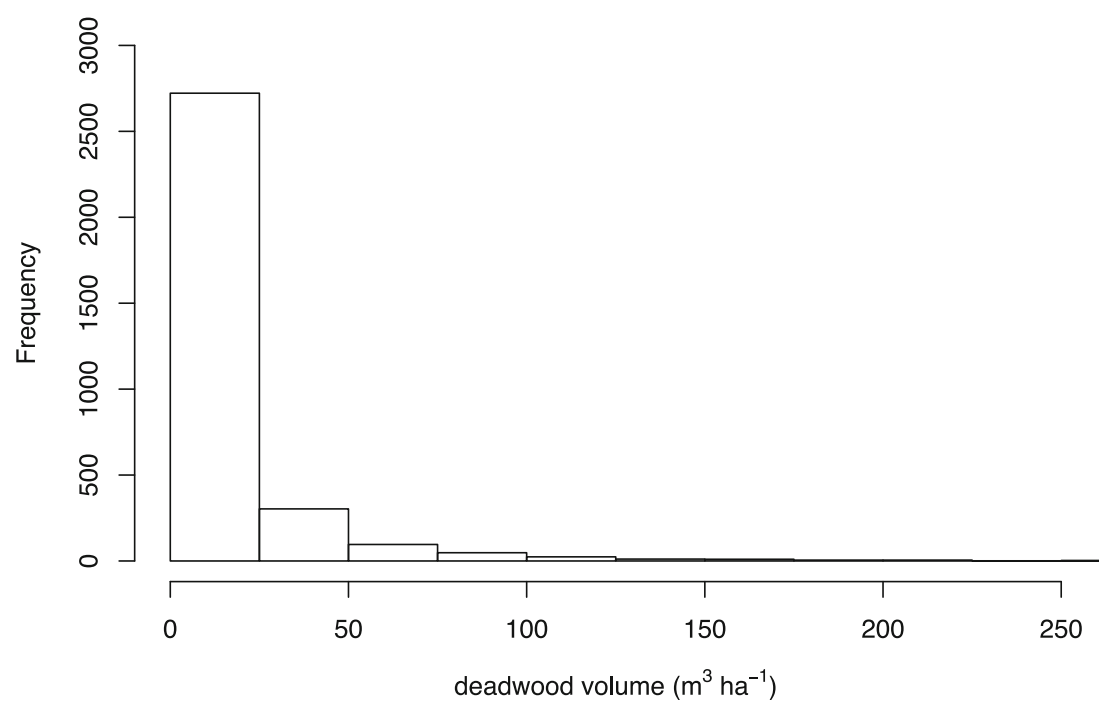

\subsection{Deadwood volume at country level}

At country level, the amount of deadwood ranges from 5.6 to $33.1 \mathrm{~m}^{3} \mathrm{ha}^{-1}$, with an average value of $15.8 \mathrm{~m}^{3} \mathrm{ha}^{-1}$ (Table 2). Deadwood is mostly present in Central Europe, particularly in Slovenia (more than $30 \mathrm{~m}^{3} \mathrm{ha}^{-1}$ ), Germany $\left(29.6 \mathrm{~m}^{3} \mathrm{ha}^{-1}\right.$ ), Slovak Republic $\left(27.3 \mathrm{~m}^{3} \mathrm{ha}^{-1}\right)$, Latvia $\left(26.4 \mathrm{~m}^{3} \mathrm{ha}^{-1}\right)$, Austria $\left(23.7 \mathrm{~m}^{3} \mathrm{ha}^{-1}\right)$, and France $\left(22.3 \mathrm{~m}^{3} \mathrm{ha}^{-1}\right)$ but high values are found also in Cyprus $\left(26.9 \mathrm{~m}^{3} \mathrm{ha}^{-1}\right)$ and Sweden $\left(24.4 \mathrm{~m}^{3} \mathrm{~h}^{-1}\right)$.

The plot frequency distribution with respect to deadwood amount is an inverse J-shaped: in about $12 \%$ of plots (374 over a total of 3243) deadwood is totally absent; in $72 \%$ of the plots with deadwood, volume is lower than 25 $\mathrm{m}^{3} \mathrm{ha}^{-1}$ (Fig. 2). SDTs are absent in about $77 \%$ of the plots (2495), LDTs in 95\% (3072), CWD in 43\% (1390), snags in $86 \%$ (2802), and stumps in $28 \%$ (900). The highest deadwood values, with a volume greater than $500 \mathrm{~m}^{3}$ $\mathrm{ha}^{-1}$, are reached in two plots from France $\left(883 \mathrm{~m}^{3} \mathrm{ha}^{-1}\right.$ and $\left.574 \mathrm{~m}^{3} \mathrm{ha}^{-1}\right)$, one from Poland $\left(647 \mathrm{~m}^{3} \mathrm{ha}^{-1}\right)$, and one from the UK $\left(630 \mathrm{~m}^{3} \mathrm{ha}^{-1}\right)$.

\subsection{European Forest Types and Categories}

Table 3 shows values of deadwood distinguished by EFTs (Barbati et al. 2014): the forest type with the highest value of deadwood volume (about $26 \mathrm{~m}^{3} \mathrm{ha}^{-1}$ ) is Alpine coniferous forest (EFT 3). In Fig. 3, the mean deadwood values by EFTs found in this study are compared with the ones obtained from NFIs in Europe (Rondeux et al. 2012). Higher differences in forest deadwood volume between this paper and NFI can be observed in EFT 5, 6, 7, 10, 13, and 14 (Fig. 3).
Table 3 Mean values of deadwood volume $\left(\mathrm{m}^{3} \mathrm{ha}^{-1}\right)$ and their $95 \%$ confidence interval estimates distinguished by European Forest Types (EFT)

\begin{tabular}{lll}
\hline EFT code & EFT name & Mean volume $\left(\mathrm{m}^{3} \mathrm{ha}^{-1}\right)$ \\
\hline 1 & Boreal forest & $10.7^{ \pm 1.9}$ \\
2 & Hemiboreal and nemoral coniferous and mixed & $14.8^{ \pm 3.5}$ \\
3 & $\quad$ broadleaved-coniferous forest & \\
4 & Alpine coniferous forest & $26.0^{ \pm 5.7}$ \\
5 & Acidophilous oak and oak-birch forest & $12.2^{ \pm 3.9}$ \\
6 & Mesophytic deciduous forest & $23.9^{ \pm 9.5}$ \\
7 & Beech forest & $23.8^{ \pm 4.2}$ \\
8 & Mountainous beech forest & $25.4^{ \pm 7.5}$ \\
9 & Thermophilous deciduous forest & $11.2^{ \pm 4.2}$ \\
10 & Broadleaved evergreen forest & $2.5^{ \pm 1.3}$ \\
11 & Coniferous forests of the Mediterranean, Anatolian, & $16.4^{ \pm 12.5}$ \\
12 & and Macaronesian regions & $6.5^{ \pm 2.7}$ \\
13 & Mire and swamp forest & $10.1^{ \pm 4.3}$ \\
14 & Floodplain forest & $20.3^{ \pm 11.9}$ \\
\hline
\end{tabular}


Fig. 3 Distribution of mean deadwood volume $\left(\mathrm{m}^{3} \mathrm{ha}^{-1}\right)$ by European Forest Types. Grey line shows values from National Forest Inventories data (see Rondeux et al. 2012, Table 2), black line the ones from results of this work

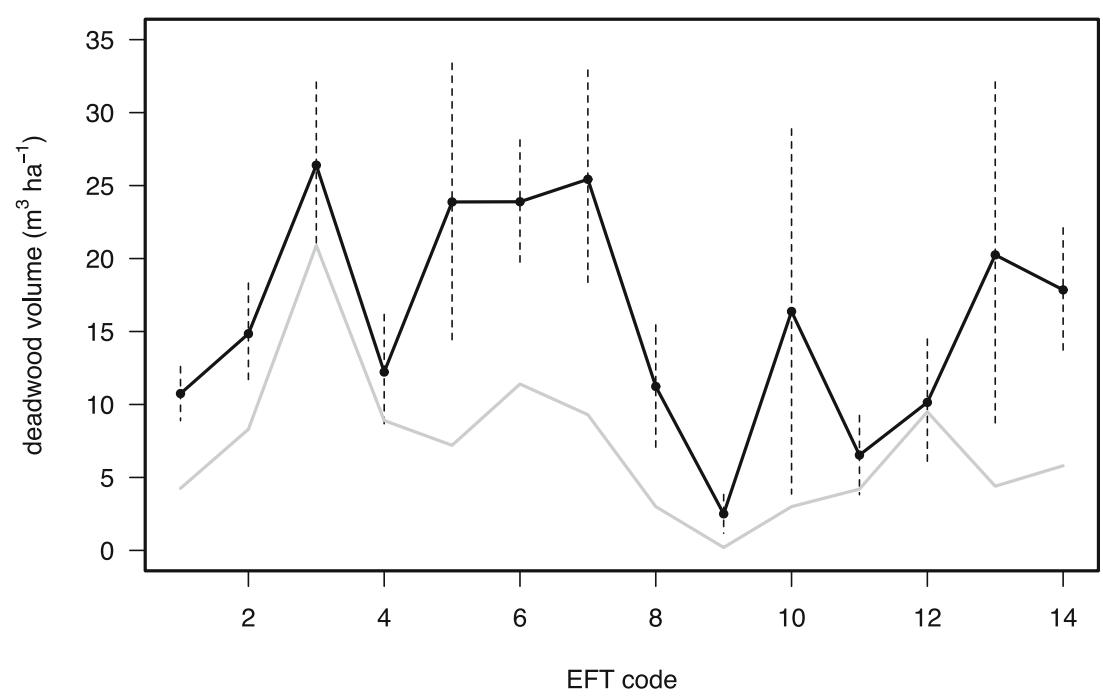

\subsection{Decay status}

The deadwood volume shows a J-shaped distribution with respect to the five decay classes. Decay class 1 is absent in 1934 plots $(60 \%)$, decay class 2 in 1449 plots (45\%), decay class 3 in 1423 plots (44\%), decay class 4 in 1277 plots (39\%), and decay class 5 in 1892 plots (58\%).

The mean values of deadwood within classes from 1 to 5 are, respectively, $3.78( \pm 0.6) \mathrm{m}^{3} \mathrm{ha}^{-1}, 3.58( \pm 0.5) \mathrm{m}^{3} \mathrm{ha}^{-1}$, $3.01( \pm 0.5) \mathrm{m}^{3} \mathrm{ha}^{-1}, 2.97( \pm 0.4) \mathrm{m}^{3} \mathrm{ha}^{-1}$, and $1.41( \pm 0.2) \mathrm{m}^{3}$ $\mathrm{ha}^{-1}$. The main proportion of deadwood volume refers to decay class 2 for both standing and lying dead trees, while decay class 3 and decay class 4 are the most frequent for CWD, snags and stumps (Fig. 4).

\subsection{Stand management}

Deadwood volume is larger in unmanaged stands. Decay class 1 is relatively dominant in both managed and unmanaged stands (25.4\% and $27.8 \%$ of all decay classes respectively) and deadwood amount decreases with increasing decay levels, with exception of decay class 3 in the case of unmanaged stands.

\subsection{Stand age}

Deadwood volume shows increasing values with stand age. Mean values range from $5.6 \mathrm{~m}^{3} \mathrm{ha}^{-1}$ of the first age class $(0$ 20 years) to $22.3 \mathrm{~m}^{3} \mathrm{ha}^{-1}$ of plots with stand age higher than 120 years. The maximum values are reached in the unevenaged stands $\left(30.4 \mathrm{~m}^{3} \mathrm{ha}^{-1}\right)$.

\section{Reuse potential and limits}

Any rational decision related to the maintenance and enhancement of the multiple functions provided by forests needs to be based on objective, reliable information (Corona 2018): as such, the dataset here presented provides substantial matter grounded on transparent methodology, coherent with the
Fig. 4 Percentage of the volume of deadwood by type and decay classes. SDT, standing dead trees; LDT, lying dead trees; CWD, coarse woody debris; SNAG, snags; STUMP, stumps. Decay classes: 1, No evidence of decay; 2, Solid wood; 3 , Slightly decayed; 4, Decomposed wood; 5 , Very decomposed wood
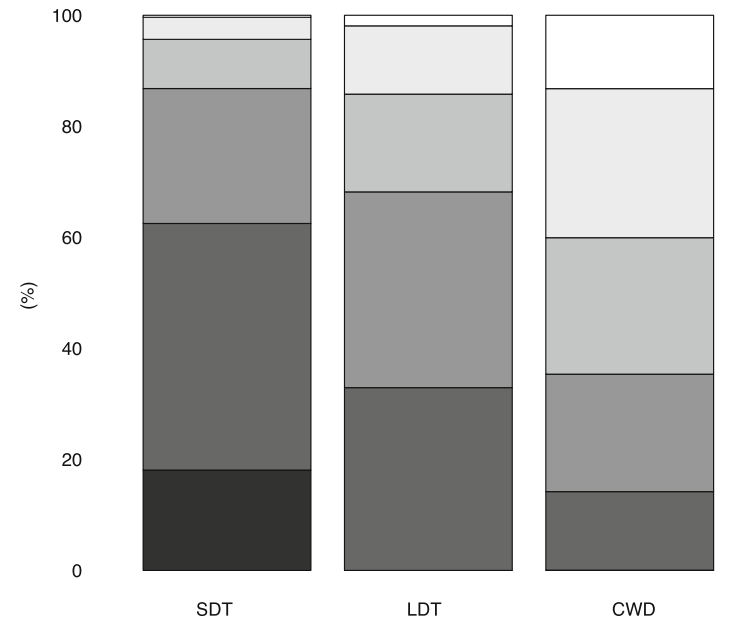

CWD

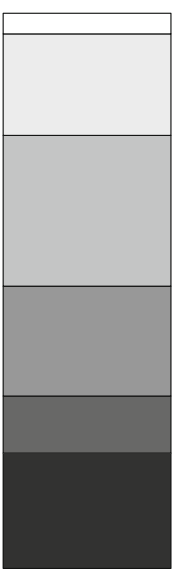

SNAG

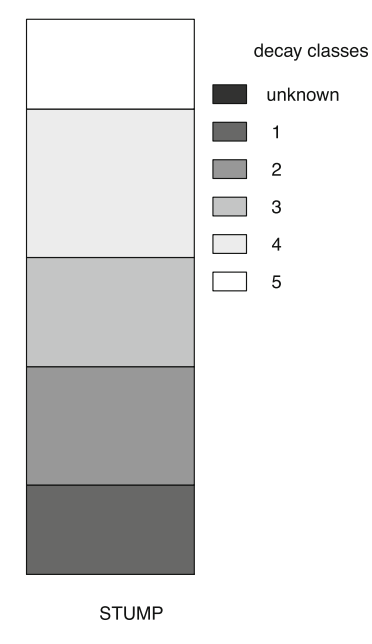

Deadwood type 


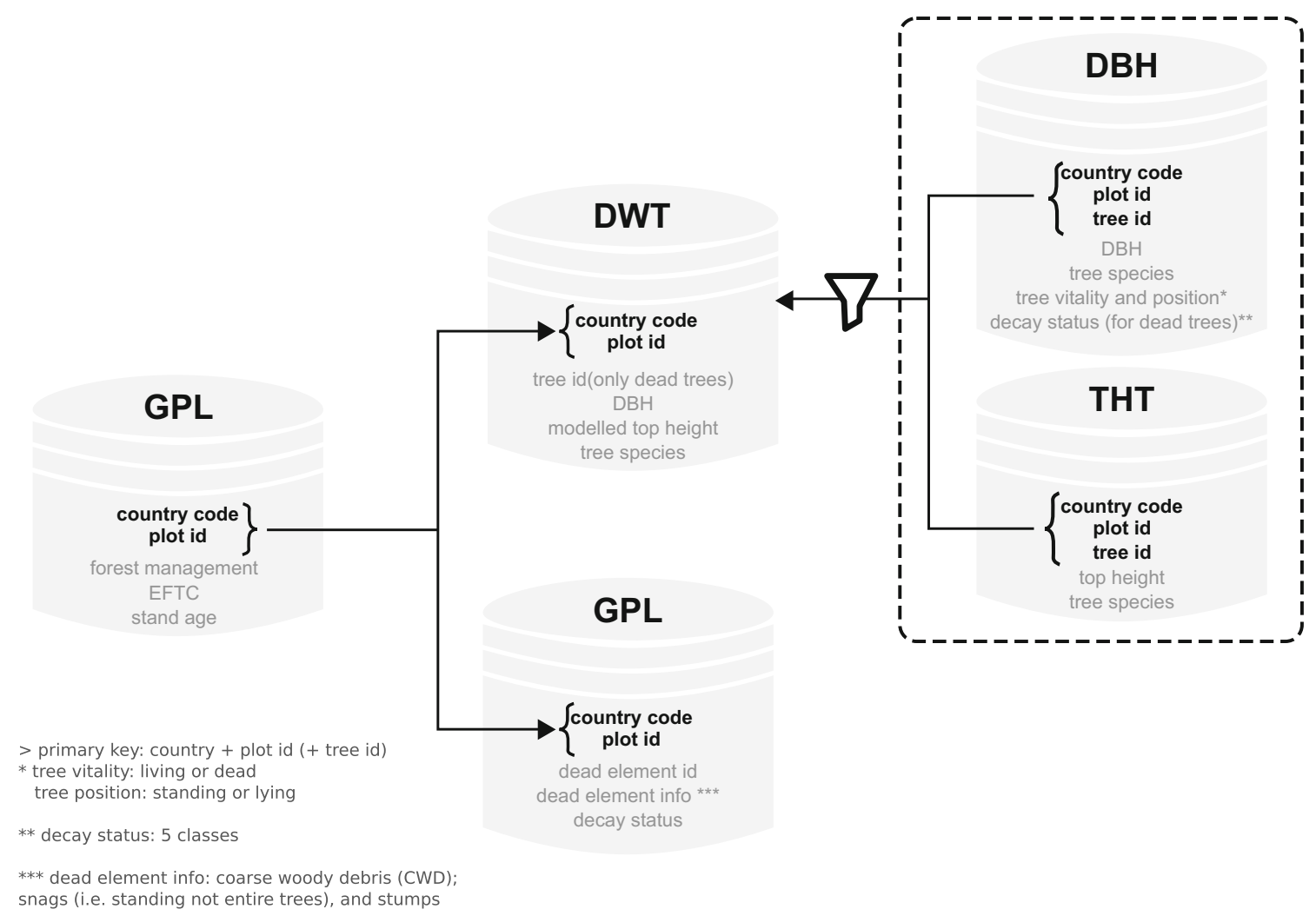

Fig. 5 ICP Forests database structure and links with dataset presented in this paper. GPL, General Plot Location and information; DWD, dead material lying on the ground; THT, Tree Top and crown base Height; $\mathrm{DBH}$, tree diameter, status, and composition; DWT, deadwood trees

(standing dead material). DBH and THT have been used to calculate volume of standing trees, DWD to calculate volume of material lying on the ground. See the text for details

request form is provided. The requesting part has to provide an abstract on the scientific purpose and approach to PCC, which will be evaluated by the ICP Forests, and the expected delivery data will be communicated after a couple of weeks. The evaluation was based on data that are part of the UNECE ICP Forests PCC Collaborative Database (see www.icpforests.org). Particularly, data from 19 countries (see $\S$ Methods), were used in the analyses. Data evaluation was co-financed by a scholarship fund of the Forest Research Institute (IBL), Poland.

\section{Compliance with ethical standards}

Conflict of interest The authors declare that there is no conflict of interest.

\section{References}

Barbati A, Marchetti M, Chirici G, Corona P (2014) European Forest Types and Forest Europe SFM indicators: tools for monitoring progress on forest biodiversity conservation. For Ecol Manag 321:145157. https://doi.org/10.1016/j.foreco.2013.07.004

Bastrup-Birk A, Neville P, Chirici G, Houston T (2008) Biosoil forest Biodiversity field manual. In: Coenen S, Sioen G, Roskams P (Eds) Demonstratieproject Biosoil - biodiversiteit in de internationale proefvlakken van het bosvitaliteitsmeetnet (Forest Focus - Biosoil Demonstration Project/Level I Forest Biodiversity Module) INBO.R.2008.52: 45-70 Instituut voor Natuur- en Bosonderzoek, Brussel ISSN: 1782-9054. Available in file "Excerpt from BE
Acknowledgements The presented derivate aggregated database is based on four original datasets (GPL, THT, DWD, and DBH) as archived into the collaborative ICP Forests database, at the Programme Co-ordinating Centre (PCC) of UNECE ICP Forests in Eberswalde, Germany. Access to these data can be requested via the official project homepage (http://icpforests.net). Under the menu "Plots and data - data requests", the data 
Demonstratieproject_biosoil_2008.pdf" at https://doi.org/10.5281/ zenodo. 1467784

Canullo R (2016) The ICP-Forests Level I biodiversity data. A harmonized data source and baseline for plant species and structural diversity on European forest ecosystems. In: Michel A, Seidling W (eds): Forest condition in Europe: 2016 Technical Report of ICP-Forests. Report under the UNECE Convention on Long-Range Transboundary Air Pollution (CLRTAP). BFW-Dokumentation 23: 89-105. Vienna: BFW Austrian Research Centre for Forests. ISBN 978-3-902762-65-8

Corona P (2018) Communicating facts, findings and thinking to support evidence-based strategies and decisions. Ann Silvicultural Res 42: 1-2. https://doi.org/10.12899/ASR-1617

Corona P, Blasi C, Chirici G, Facioni L, Fattorini L, Ferrari B (2010) Monitoring and assessing old-growth forest stands by plot sampling. Plant Biosystems 144:171-179. https://doi.org/10.1080/ 11263500903560710

EEA (2006). European forest types categories and types for sustainable forest management reporting and policy. Technical report, Eur Environ Agency; Technical report No 9/2006, 114 pp.

Ferretti M, Fischer R (eds) (2013) Forest monitoring: methods for terrestrial investigations in Europe with an overview of North America and Asia, vol 12. Developments in Environmental Science, Oxford, p 536

Fleck S, Cools N, De Vos B, Meesenburg H, Fischer R (2016) The Level II aggregated forest soil condition database links soil physicochemical and hydraulic properties with long-term observations of forest condition in Europe. Ann For Sci 73:945-957. https://doi.org/10. 1007/s13595-016-0571-4

Haußmann T, Fischer R (2004) The Forest Monitoring Programme of ICP-Forests - a contribution to biodiversity monitoring. In: Marchetti M (ed) Monitoring and indicators of forest biodiversity in Europe - from ideas to operationality, vol 51, pp 413-419

Hunter ML (1990) Wildlife, forests, and forestry: principles of managing forests for biological diversity. Prentice and Hall, Englewood Cliffs, p 270

Lassauce A, Paillet Y, Jactel H, Bouget C (2011) Deadwood as a surrogate for forest biodiversity: meta-analysis of correlations between deadwood volume and species richness of saproxylic organisms. Ecol Indic 11(5):1027-1039. https://doi.org/10.1016/j.ecolind. 2011.02.004

Lombardi F, Marchetti M, Corona P, Merlini P, Chirici G, Tognetti R, Burrascano S, Alivernini A, Puletti N (2015) Quantifying the effect of sampling plot size on the estimation of structural indicators in oldgrowth forest stands. For Ecol Manag 346(15):89-97. https://doi. org/10.1016/j.foreco.2015.02.011

Puletti N, Giannetti F, Chirici G, Canullo R (2017) Deadwood distribution in European forests. J Maps 13(2):733-736. https://doi.org/10. 1080/17445647.2017.1369184

Puletti N, Canullo R, Mattioli W, Gawrys Radosław, Corona P, Czerepko $\mathrm{J}$ (2018) Forest deadwood in Europe Version 4 Zenodo. [Dataset] https://doi.org/10.5281/zenodo.1467784

Rondeux J, Bertini R, Bastrup-Birk A, Corona P, Latte N, McRoberts RE, Ståhl G, Winter S, Chirici G (2012) Assessing deadwood using harmonized national forest inventory data. For Sci 58:269-283. https://doi.org/10.5849/forsci.10-057

Seibold S, Bässler C, Brandl R, Gossner MM, Thorn S, Ulyshen MD, Müller J (2015) Experimental studies of dead-wood biodiversity - a review identifying global gaps in knowledge. Biol Conserv Volume 191, November 2015: 139-149. https://doi.org/10.1016/j.biocon. 2015.06.006

Ståhl G, Cienciala E, Chirici G, Lanz A, Vidal C, Winter S, McRoberts RE, Rondeux J, Schadauer K, Tomppo E (2012) Bridging national and reference definitions for harmonizing forest statistics. For Sci 58(3):214-223. http:/dx.doi.org. https://doi.org/10.5849/forsci.10067

Wilkinson MD, Dumontier M, Aalbersberg IJ, Appleton G, Axton M, Baak A, Blomberg N, Boiten JW, da Silva Santos LB, Bourne PE, Bouwman J, Brookes AJ, Clark T, Crosas M, Dillo I, Dumon O, Edmunds S, Evelo CT, Finkers R, Gonzalez-Beltran A, Gray AJG, Groth P, Goble C, Grethe JS, Heringa J, Hoen PAC, Hooft R, Kuhn T, Kok R, Kok J, Lusher SJ, Martone ME, Mons A, Packer AL, Persson B, Rocca-Serra P, Roos M, van Schaik R, Sansone SA, Schultes E, Sengstag T, Slater T, Strawn G, Swertz MA, Thompson M, van der Lei J, van Mulligen E, Velterop J, Waagmeester A, Wittenburg P, Wolstencroft K, Zhao J, Mons B (2016) The FAIR Guiding Principles for scientific data management and stewardship. Scientific Data 3:160018. https://doi.org/10.1038/ sdata.2016.18

Zell J, Kändler G, Hanewinkel M (2009) Predicting constant decay rates of coarse woody debris - a meta-analysis approach with a mixed model. Ecol Model 220(7):904-912. https://doi.org/10.1016/j. ecolmodel.2009.01.020

Publisher's note Springer Nature remains neutral with regard to jurisdictional claims in published maps and institutional affiliations. 